\title{
Effect of Organic Inputs and Microbial Consortium on Yield and Soil Health of Knolkhol (Brassica oleracea L. var. gongylodes) Cultivation
}

\author{
Parkey Gogoi, Deepa Borbora Phookan and Utpal Das*
}

Department of Horticulture, Assam Agricultural University, Assam, India

*Corresponding author

A B S T R A C T

\section{Keywords \\ Organic, Vermicompost, Enriched compost, \\ Consortium, Soil parameters}

\section{Article Info}

Accepted:

28 March 2018

Available Online:

10 April 2018
The present investigation was carried out to study the yield of knolkhol and the soil health as influenced by organic inputs and microbial consortium at experimental farm, Department of Horticulture, Jorhat during 2014-15 and 2015-16. Pooled data over two years revealed that $\mathrm{T}_{8}$ [RDF (80:60:60kg NPK + 10t FYM ha $\left.{ }^{-1}\right)$ ] recorded the highest knob yield of $191.45 \mathrm{q} \mathrm{ha}^{-1}$ which was followed by $169.73 \mathrm{q} \mathrm{ha}^{-1}$ under $\mathrm{T}_{7}$ (Enriched compost $5 \mathrm{t}$ $\left.\mathrm{ha}^{-1}\right)$. Soil parameters studies revealed that soil $\mathrm{pH}(5.62), \mathrm{N}\left(293.82 \mathrm{~kg} \mathrm{ha}^{-1}\right), \mathrm{P}(66.91 \mathrm{~kg}$ $\left.\mathrm{ha}^{-1}\right)$, K (141.22 $\left.\mathrm{kg} \mathrm{ha}^{-1}\right)$, MBC $\left(315.94 \mu \mathrm{g} \mathrm{g}^{-1}\right.$ soil), dehydrogenase $\left(233.87 \mu \mathrm{g}_{\mathrm{TPF}} \mathrm{g}^{-1}\right.$ soil), phosphomonoesterase (413.77 $\mu \mathrm{g}$ p-nitophenol $\mathrm{g}^{-1}$ soil), fluorescein diacetate (8.60

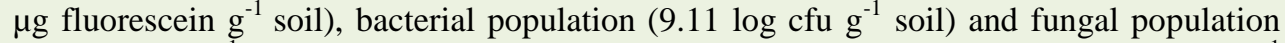
(6.11 log cfu g ${ }^{-1}$ soil) were found better in treatment treated with Enriched compost $5 \mathrm{t} \mathrm{ha}^{-1}$ and consortium $\left(\mathrm{T}_{7}\right)$. However, organic carbon $(0.92 \%)$ was found to be better in $\mathrm{T}_{5}\left(\mathrm{~T}_{1}+\right.$ Vermicompost $5 \mathrm{t} \mathrm{ha}^{-1}$ ).

\section{Introduction}

Knolkhol (Brassica oleracea L. var. gongylodes) is a cole crop which is a good source of vitamins, minerals and fibres. As the crop is a heavy feeder of nutrients and excavates $\mathrm{N}, \mathrm{P}$ and $\mathrm{K}$ from soil to a great extent, judicious application of manures and biofertilizers is essential to obtain higher yield and enhanced soil health.

In modern agriculture, continuous and indiscriminate use of chemical fertilizers, pesticides and herbicides deteriorates the soil health, causes human health hazards and creates imbalance in the environment. The continuous use of chemical fertilizers badly affects the texture and structure of soil, reduces soil organic matter and decreases microbial activity of soil (Alam et al., 2007). This led many farmers to switch over to organic farming in recent times to produce safe foodstuff and to get higher price from the market.

Suitable combination of organic nutrients for improvement of growth and yield of knolkhol has been a matter of interest to the farmers. But suitable recommendations are scarce especially for NE India. Keeping the above facts in view, the present study was carried out for future production. 


\section{Materials and Methods}

The experiment was conducted at the Experimental Farm, Department of Horticulture, Assam Agricultural University, Jorhat during 2014-15 and 2015-16 using the variety White Vienna. The experimental site was established under a Randomized Block Design with eight treatments and three replications under open condition. The treatments were: $\mathrm{T}_{1}=$ Rock phosphate + Consortium, $\mathrm{T}_{2}=\mathrm{T}_{1}+$ Compost $\left(2.5 \mathrm{tha}^{-1}\right), \mathrm{T}_{3}$ $=\mathrm{T}_{1}+$ Compost $\left(5 \mathrm{t} \mathrm{ha}^{-1}\right), \mathrm{T}_{4}=\mathrm{T}_{1}+$ Vermicompost $\left(2.5 \mathrm{t} \quad \mathrm{ha}^{-1}\right), \quad \mathrm{T}_{5}=\mathrm{T}_{1}+$ Vermicompost $\left(5 \mathrm{t} \mathrm{ha}^{-1}\right), \mathrm{T}_{6}=$ Enriched compost $\left(2.5 \mathrm{tha}^{-1}\right), \mathrm{T}_{7}=$ Enriched compost $(5 \mathrm{t}$ $\left.\mathrm{ha}^{-1}\right)$ and $\mathrm{T}_{8}=\mathrm{RDF}\left(80: 60: 60 \mathrm{~kg} \mathrm{ha}^{-1} \mathrm{NPK}\right)+$ FYM @ 10t ha ${ }^{-1}$. The recommended dose of fertilizer was applied in the form of urea $(\mathrm{N}-$ 46\%), SSP (P - 16\%) and MOP (K- 60\%) along with borax $\left(60 \mathrm{~kg} \mathrm{ha}^{-1}\right)$. All the organic manures were applied once as a basal dose and incorporated in the soil 15 days before transplanting of seedlings. Half dose of urea, full dose of SSP, MOP and borax were applied as basal dose and remaining half of urea was applied as top-dress at 30 days after transplanting. Except the inorganic treatment, all other treatments were mixed with a slurry of consortium before sowing. Seedlings were transplanted in the month of October with a spacing of $40 \times 30 \mathrm{~cm}$. The observations were made by using standard procedures and the data were analysed as per statistical methods given by Panse and Sukhatme (1995).

\section{Results and Discussion}

\section{Knob yield per hectare}

It was revealed in Figure 1 that highest knob yield $\mathrm{ha}^{-1}$ of $189.35 \mathrm{q}, 195.56 \mathrm{q}$ and $191.45 \mathrm{q}$ were recorded in $\mathrm{T}_{8}$ [RDF (80:60:60kg NPK + $10 \mathrm{tha}^{-1}$ FYM)] in the year 2014-2015, 20152016 and pooled data over two years respectively. This could be due to the ready availability and utilization of nutrients for various internal processes in the plant. Among the different organic treatments, $\mathrm{T}_{7}$ (Enriched compost $5 \mathrm{t} \mathrm{ha}^{-1}$ ) exhibited the highest yield $\mathrm{ha}^{-1}$ of 169.73q. However, $\mathrm{T}_{1}$ (Rock phosphate + Consortium) was recorded with the lowest knob yield ha ${ }^{-1}$ of $46.99 q$. Increase in the yield was due to the supply of additional nutrients through organics as well as improvement in the physical and biological properties of soil (Sharma et al., 2005). Application of organic manure increases microbial population in soil that helps the soil to release various immobile nutrients. These microbes also produce PGRs that are important for plant growth and photosynthetic activity (Levy and Taylor, 2003).

\section{Soil pH}

Pooled data over two years in Table 1 revealed that $\mathrm{T}_{7}$ (Enriched compost $5 \mathrm{t} \mathrm{ha}^{-1}$ ) and $\mathrm{T}_{8}$ [RDF (80:60:60kg NPK + 10t FYM ha ${ }^{-1}$ )] exhibited the highest soil $\mathrm{pH}$ value of 5.62 and 4.72 respectively. Higher $\mathrm{pH}$ in the organic treatments might be due to deactivation of $\mathrm{Al}^{3+}$ and concomitant release of basic cations due to addition of organic matter (Gogoi, 2010).

\section{Soil organic carbon (\%)}

The highest organic carbon of $0.94 \%, 0.91 \%$ and $0.92 \%$ were recorded in the first year, second year and pooled data over two years respectively in $T_{5}\left(T_{1}+\right.$ Vermicompost $5 t$ $h^{-1}{ }^{-1}$. However, pooled data revealed that $\mathrm{T}_{8}$ [RDF (80:60:60kg NPK + 10t ha ${ }^{-1}$ FYM)] recorded significantly the lowest soil organic carbon of $0.66 \%$. Increased organic carbon in $\mathrm{T}_{5}$ might be due to relatively higher carbon content compared to other organic and inorganic treatments. The lowest organic carbon in $\mathrm{T}_{8}$ might be due to the fact that it does not contain any organic matter (GarcíaRuiz, 2008). 
Table.1 Soil pH, organic carbon, microbial biomass carbon and fluorescein di-acetate

\begin{tabular}{|c|c|c|c|c|c|c|c|c|c|c|c|c|}
\hline \multirow[t]{2}{*}{ Treatments } & \multicolumn{3}{|c|}{ pH } & \multicolumn{3}{|c|}{ Organic Carbon (\%) } & \multicolumn{3}{|c|}{$\begin{array}{l}\text { Microbial Biomass Carbon } \\
\left(\mu \mathrm{g} \mathrm{g}^{-1} \text { soil } 24 \text { hour }^{-1}\right)\end{array}$} & \multicolumn{3}{|c|}{$\begin{array}{c}\text { Fluorescein Di-acetate } \\
\text { ( } \mu \mathrm{g} \text { fluorescein } \mathrm{g}^{-1} \text { soil hour }{ }^{-1} \text { ) }\end{array}$} \\
\hline & $\begin{array}{l}2014- \\
2015\end{array}$ & $\begin{array}{c}2015- \\
2016\end{array}$ & Pooled & $\begin{array}{c}2014- \\
2015\end{array}$ & $\begin{array}{l}2015- \\
2016\end{array}$ & Pooled & $\begin{array}{c}\text { 2014- } \\
2015\end{array}$ & $\begin{array}{c}2015- \\
2016\end{array}$ & Pooled & $\begin{array}{c}\text { 2014- } \\
2015\end{array}$ & $\begin{array}{c}2015- \\
2016\end{array}$ & Pooled \\
\hline$T_{2}$ & 5.08 & 5.36 & 5.22 & 0.75 & 0.85 & 0.80 & 236.71 & 242.20 & 239.45 & 6.17 & 6.34 & 6.25 \\
\hline $\mathbf{T}_{3}$ & 5.16 & 5.54 & 5.35 & 0.73 & 0.79 & 0.76 & 245.37 & 248.35 & 246.86 & 6.88 & 6.78 & 6.83 \\
\hline$T_{6}$ & 5.21 & 5.45 & 5.33 & 0.84 & 0.88 & 0.86 & 294.53 & 298.68 & 296.60 & 8.35 & 8.67 & 8.51 \\
\hline$T_{7}$ & 5.68 & 5.56 & 5.62 & 0.89 & 0.88 & 0.88 & 310.87 & 321.02 & 315.94 & 8.92 & 9.29 & 8.60 \\
\hline$T_{8}$ & 4.66 & 4.78 & 4.72 & 0.67 & 0.65 & 0.66 & 230.91 & 233.17 & 232.04 & 5.96 & 6.00 & 5.98 \\
\hline S.Ed ( \pm$)$ & 0.08 & 0.08 & 0.06 & 0.02 & 0.04 & 0.03 & 0.51 & 0.72 & 0.66 & 0.30 & 0.26 & 0.32 \\
\hline CD (5\%) & 0.17 & 0.16 & 0.13 & 0.05 & 0.07 & 0.06 & 1.15 & 1.47 & 1.32 & 0.66 & 0.69 & 0.73 \\
\hline
\end{tabular}

Table.2 Dehydrogenase activity, phosphomonoesterase activity, bacterial population and fungal population

\begin{tabular}{|c|c|c|c|c|c|c|c|c|c|c|c|c|}
\hline \multirow[t]{2}{*}{$\begin{array}{l}\text { Treat- } \\
\text { ments }\end{array}$} & \multicolumn{3}{|c|}{ 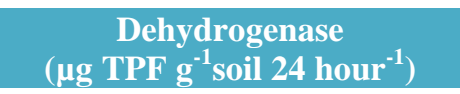 } & \multicolumn{3}{|c|}{$\begin{array}{c}\text { Phosphomonoesterase } \\
\left(\mu \mathrm{g} \text { p-nitrophenol } \mathrm{g}^{-1} \text { soil hour }{ }^{-1} \text { ) }\right.\end{array}$} & \multicolumn{3}{|c|}{$\begin{array}{l}\text { Bacterial population } \\
\quad\left(\log \mathrm{cfu} \mathrm{g}^{-1} \text { soil }\right)\end{array}$} & \multicolumn{3}{|c|}{$\begin{array}{l}\text { Fungal population } \\
\quad\left(\log \mathrm{cfu}^{-1} \text { soil) }\right.\end{array}$} \\
\hline & $\begin{array}{c}2014- \\
2015\end{array}$ & $\begin{array}{l}2015- \\
2016\end{array}$ & Pooled & $\begin{array}{c}2014- \\
2015\end{array}$ & 2015-2016 & Pooled & $\begin{array}{l}2014- \\
2015\end{array}$ & 2015-2016 & Pooled & $\begin{array}{l}2014- \\
2015\end{array}$ & 2015-2016 & Pooled \\
\hline$\overline{T_{1}}$ & 168.83 & 173.24 & 171.03 & 335.26 & 331.87 & 333.56 & 6.58 & 6.75 & 6.66 & 5.21 & 5.35 & 5.28 \\
\hline$T_{2}$ & 157.83 & 160.90 & 159.37 & 312.51 & 321.37 & 316.94 & 6.83 & 6.88 & 6.85 & 5.30 & 5.28 & 5.29 \\
\hline$\overline{T_{3}}$ & 176.90 & 185.87 & 181.38 & 342.29 & 351.25 & 346.77 & 7.12 & 8.15 & 7.63 & 5.68 & 5.76 & 5.72 \\
\hline$\overline{T_{4}}$ & 189.26 & 197.97 & 193.61 & 369.29 & 372.20 & 370.74 & 7.59 & 7.86 & 7.72 & 5.44 & 5.51 & 5.47 \\
\hline$\overline{T_{5}}$ & 218.41 & 223.97 & 221.19 & 379.78 & 382.62 & 381.2 & 8.16 & 8.09 & 8.12 & 5.78 & 5.90 & 5.84 \\
\hline$T_{6}$ & 203.88 & 206.89 & 205.38 & 396.70 & 402.19 & 399.44 & 8.25 & 8.27 & 8.26 & 5.96 & 5.98 & 5.97 \\
\hline $\mathbf{T}_{7}$ & 229.26 & 238.47 & 233.87 & 412.37 & 415.18 & 413.77 & 9.05 & 9.18 & 9.11 & 6.15 & 6.07 & 6.11 \\
\hline $\mathrm{T}_{8}$ & 128.11 & 133.38 & 130.74 & 287.54 & 295.62 & 291.58 & 6.48 & 6.66 & 6.57 & 5.17 & 5.26 & 5.21 \\
\hline S.Ed $( \pm)$ & 0.42 & 0.49 & 0.30 & 0.30 & 0.48 & 0.28 & 0.03 & 0.01 & 0.02 & 0.03 & 0.02 & 0.01 \\
\hline CD $(5 \%)$ & 1.14 & 1.05 & 0.69 & 0.64 & 1.03 & 0.64 & 0.11 & 0.05 & 0.10 & 0.12 & 0.08 & 0.06 \\
\hline
\end{tabular}


Fig.1 Knob yield hectare ${ }^{-1}$

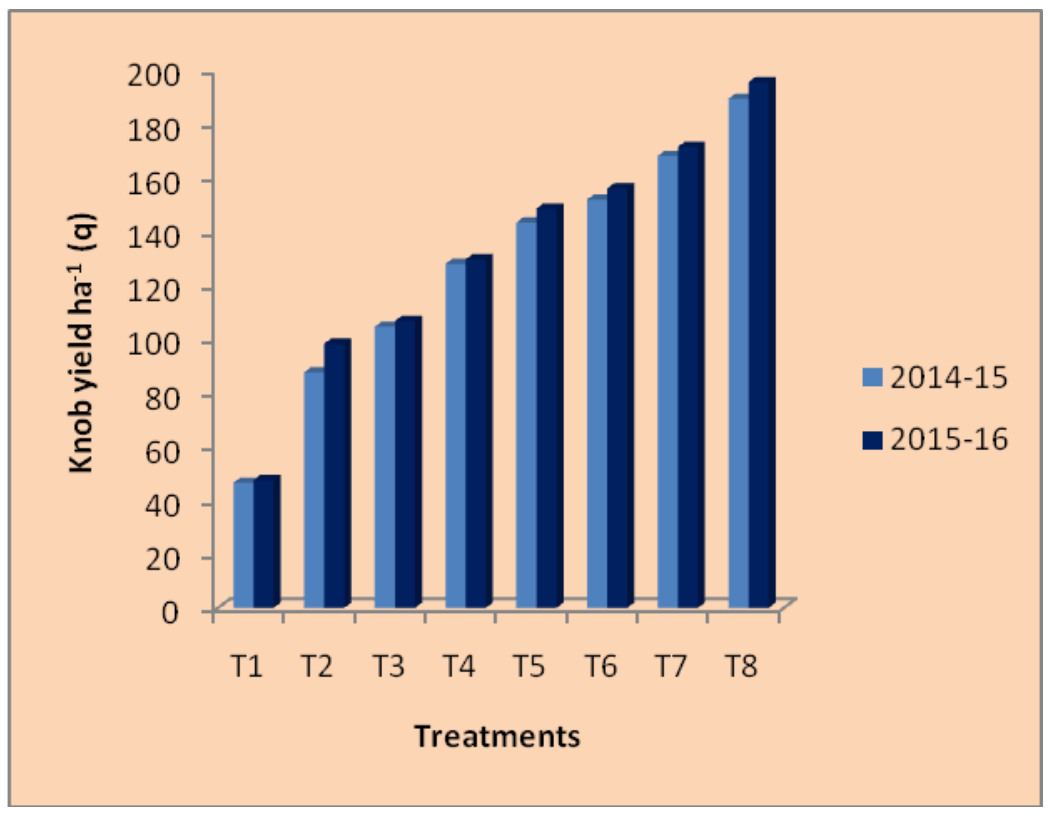

Fig.2 Available soil N, P and K

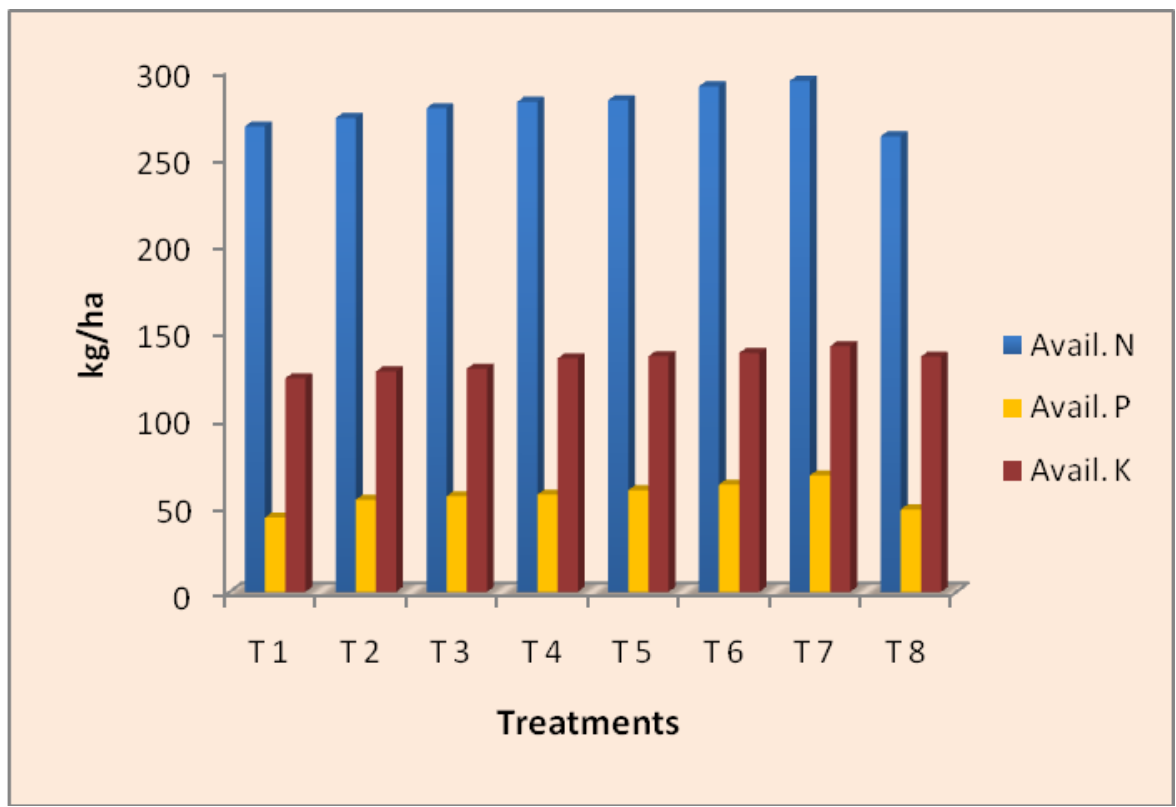

\section{Available soil nitrogen $\left(\mathrm{kg} \mathrm{ha}^{-1}\right)$}

Highest available $\mathrm{N}$ content of $293.82 \mathrm{~kg} \mathrm{ha}^{-1}$ was recorded in $\mathrm{T}_{7}$ (Enriched compost $5 \mathrm{t} \mathrm{ha}^{-1}$ ) and such a buildup of available $\mathrm{N}$ could be attributed to the ability of Rhizobium with Azotobacter to fix atmospheric $\mathrm{N}$ in the rhizosphere throughout the cropping period (Workneh et al., 1993).

The lowest nitrogen content of $261.18 \mathrm{~kg} \mathrm{ha}^{-1}$ was recorded in $\mathrm{T}_{8}$ [RDF (80:60:60kg NPK + 10t FYM ha ${ }^{-1}$ )]. This might be due to leaching and other losses with chemical fertilizers as 
compared to organic manures (Biswas and Narayanasamy, 2008).

\section{Available soil phosphorus $\left(\mathrm{kg} \mathrm{ha}^{-1}\right)$}

Available soil phosphorus status $(66.91 \mathrm{~kg}$ $\mathrm{ha}^{-1}$ ) was highest in Enriched compost $5 \mathrm{t} \mathrm{ha}^{-1}$ $\left(\mathrm{T}_{7}\right)$. It might be due to action of organic acids by phosphate solubilising bacteria act as a chelating agent and form stable complexes with $\mathrm{Fe}$ and $\mathrm{Al}$ abundantly available in the acid soils and thereby release phosphorus from clutches of $\mathrm{Fe}$ and $\mathrm{Al}$ to the soil solution. The significant decrease in soil phosphorus was recorded in $\mathrm{T}_{1}\left(42.71 \mathrm{~kg} \mathrm{ha}^{-1}\right)$ which might be due to lack of nutrient source for the microbes to utilize phosphorus during initial stage (Fig. 2).

\section{Available soil potassium (kg ha $\left.{ }^{-1}\right)$}

$\mathrm{T}_{7}$ (Enriched compost 5t ha ${ }^{-1}$ ) showed the highest potassium content of $146.34 \mathrm{~kg} \mathrm{ha}^{-1}$.

The higher availability of potassium in soil may be due to beneficial effect of organic manures on the reduction of potassium fixation; added organic matter interacted with potassium clay to release potassium from the non-exchangeable fraction to the available pool (Reddy and Reddy, 1998). However, the lowest available potassium of $122.77 \mathrm{~kg} \mathrm{ha}^{-1}$ was observed in $\mathrm{T}_{1}$.

Microbial biomass carbon $\left(\mu \mathrm{g} \mathrm{g}^{-1}\right.$ soil 24 $\mathrm{hr}^{-1}$ )

Application of Enriched compost 5t ha ${ }^{-1}\left(\mathrm{~T}_{7}\right)$ resulted in the highest $\mathrm{MBC}\left(315.94 \mu \mathrm{g} \mathrm{g}^{-1}\right.$ soil). This might be due to higher availability of substrate as carbon from applied organic source of nutrients which improves the microbial and enzymatic activities in soil (Rajkonwar, 2012). The lowest MBC was observed in $\mathrm{T}_{1}$ (Rock phosphate + Consortium).
Fluorescein di-acetate hydrolysis activity ( $\mu$ g fluorescein $\mathrm{g}^{-1}$ soil hour ${ }^{-1}$ )

Pooled data revealed that $T_{7}$ exhibited the highest fluorescein di-acetate activity of 8.60 fluorescein $\mathrm{g}^{-1}$ soil hour ${ }^{-1}$ which was at par with 8.51 fluorescein $\mathrm{g}^{-1}$ soil hour ${ }^{-1}$ in $\mathrm{T}_{6}$ (Enriched compost 2.5t ha $\mathrm{ha}^{-1}$ ). Addition of organic sources acts as a good source of carbon and energy to heterotrophs or microbes which keep them alive for a longer period of time. This is in conformity with Chang et al., (2007). However, the lowest fluorescein di-acetate activity $\left(5.65 \mu \mathrm{g} \mathrm{g}^{-1}\right.$ soil hour ${ }^{-1}$ ) was recorded in $\mathrm{T}_{1}$ (Rock phosphate + Consortium) which were at par with $5.98 \mu \mathrm{g}$ $\mathrm{g}^{-1}$ soil hour ${ }^{-1}$ in $\mathrm{T}_{8}(\mathrm{RDF})$.

Dehydrogenase activity ( $\mu$ g TPF $\mathrm{g}^{-1}$ soil $24 \mathrm{hr}^{-1}$ )

The data revealed that during the year 20142015, 2015-16 and data pooled over two year, the highest DH activity of $229.26 \mu \mathrm{g}_{\mathrm{TPF}} \mathrm{g}^{-1}$ soil 24 hour $^{-1}, 238.47 \mu \mathrm{g} \mathrm{TPFg}^{-1}$ soil 24 hour $^{-1}$ and $233.87 \mu \mathrm{g} \mathrm{TPFg}^{-1}$ soil 24 hour $^{-1}$ was recorded in $\mathrm{T}_{7}$ (Enriched compost $5 \mathrm{t} \mathrm{ha}^{-1}$ ) and the lowest DH activity of $128.11 \mu \mathrm{g}$ TPF $\mathrm{g}^{-1}$ soil 24 hour $^{-1}, 133.38 \mu \mathrm{g} \mathrm{TPFg}^{-1}$ soil 24 hour $^{-1}$ and $130.74 \mu \mathrm{g} \quad \mathrm{TPFg}^{-1}$ soil $24 \mathrm{hour}^{-1}$ respectively in the year 2014-2015, 2015-16 and data pooled over two year in $\mathrm{T}_{8}(\mathrm{RDF})$. The activity of DH enzyme in soil increased significantly due to application of organic sources. DH enzyme classified as oxidoreductase takes part in oxidation-reduction reactions, involving in transfer of $\mathrm{H}^{+}$to an acceptor other than $\mathrm{O}_{2}$. The effect of higher microbial activity and $\mathrm{MBC}$ resulted in higher DH activity (Subhani et al., 2001) (Table 2).

Phosphomonoesterase activity ( $\mu \mathrm{g}$ pnitrophenol $\mathrm{g}^{-1}$ soil $\mathbf{h r}^{-1}$ )

Pooled data revealed that the highest PMEase activity of $413.77 \mu \mathrm{g} p$-nitrophenol $\mathrm{g}^{-1}$ soil 
hour $^{-1}$ was recorded in $\mathrm{T}_{7}$ (Enriched compost $5 \mathrm{t} \mathrm{ha}^{-1}$ ) and the lowest PMEase activity of $291.58 \mu \mathrm{g} p$-nitrophenol $\mathrm{g}^{-1}$ soil hour ${ }^{-1}$ in $\mathrm{T}_{8}$ (RDF). Enriched compost showed the superior result due to the release of more organically bound $\mathrm{P}$ as synthesis of the enzyme is stimulated by the presence of organic substrate (Biswas and Narayanaswamy, 2008).

\section{Microbial population (log $\mathrm{cfu}^{-1}$ soil)}

The highest bacterial population of $9.11 \mathrm{log}$ cfu $\mathrm{g}^{-1}$ soil and fungal population of $6.11 \mathrm{log}$ cfu $\mathrm{g}^{-1}$ soil were exhibited by $\mathrm{T}_{7}$ (Enriched compost $\left.5 \mathrm{t} \mathrm{ha}^{-1}\right)$. The lowest bacterial population (6.57 log $\mathrm{cfu} \mathrm{g}^{-1}$ soil) and fungal population (5.21 log $\mathrm{cfu} \mathrm{g}^{-1}$ soil) were recorded in inorganic treatment i.e. $\mathrm{T}_{8}$. Sources of potential beneficial microbes in the enriched compost might have possibly provided microbial diversity and activity of microorganism accompanied by better $\mathrm{DH}$ and PMEase activity. Similar findings were also reported by Nath et al., (2012). Manure application is known to stimulate and improve stable soil structure, fungal and bacterial population and biological activity (Chaoui et al., 2003).

From the above study it was clearly observed that organic manures and microbial consortium had positive impact on yield of knolkhol as well as the soil health. Among the organic treatments, $\mathrm{T}_{7}$ (Enriched compost $5 \mathrm{t}$ $\mathrm{ha}^{-1}$ ) was found to be best and can be recommended for the plains of Assam after critical evaluations.

\section{References}

Alam, N., Islam, M. S., Johan, M. S. and Ali, M. K. (2007). Effect of vermicompost and NPK fertiliser on growth, yield component of red amaranthus.
Australian J. Basic Appl. Sci. 1(4): 706716.

Biswas, D. R. and Narayanasamy, G. (2008). Rock Phosphate Enriched Compost: An Approach to Improve Low Grade Indian Rock Phosphate. Biores. Technol. 97: 2243-2251.

Chang, E., Chung, R. and Tsai, Y. (2007). Effect of different application rates of organic fertilizer on soil enzyme activity and microbial population. Soil Sci. and Pl. Nutri. 53(2): 132-140.

Chaoui, H. I., Zibilske, L. M. and Ohno, T. (2003). Effects of earthworm casts and compost on soil microbial activity and plant nutrient availability. Soil Biol. and Biochem. 35: 295-302.

Garcia-Ruiz, R., Ochoa, V., Hinojosa, M.B. and Carreira, J.A. (2008). Suitability of enzymatic activities for the monitoring of soil quality improvement in organic agricultural systems. Soil Biol. Biochem. 40: 2137-2145.

Gogoi, B., Barua, N. G. and Baruah, T. C. (2010). Effect of integrated supply of nutrient on soil microbial biomass carbon in an inceptisol of Assam. $J$. Indian Soc. Soil Sci. 58(2):241-244.

Levy, J. S. and Taylor, B. R. (2003). Effects of pulp mill solids and there composts on early growth of tomatoes. Biores. Technol. 89(3): 297-305.

Nath, D. J., Ozah, B., Baruah, R., Barooah, R.C., Borah, D.K. and Gupta, M. (2012). Soil enzymes and microbial biomass carbon under Rice-Toria sequence as influenced by nutrient management. J. Indian Soc. Soil Sci. 60: 20-24.

Panse, V. G. and Sukhatme, P. V. (1978). Statistical Methods for Agricultural Workers. Indian Council of Agricultural Research, New Delhi.

Reddy, G. B. and Reddy, S.M. (1998). Effect of organic manures and nitrogen levels of soil available nutrient status in 
maize-soybean cropping system. $J$. Indian. Soc. Soil Sci. 46: 474-476.

Sharma, R. P., Sharma, A. and Sharma, J. K (2005). Productivity, nutrient uptake, soil fertility and economis as affected by chemical fertilizers and farm yard manure in broccoli (Brassica oleracea var. italica) in an entisol. Indian $J$. Agric. Sci. 75(9): 576-579.

Subhani, A., Changyong, H., Zhengmiao, Y., Min, L. and El-ghamry, A. (2001): Impact of soil environment and agronomic practices on microbial dehydrogenase enzyme activity in soil -
A Review. Pakistan J. Biol. Sci. 4: 333338.

Tekasangla, A., Kanaujia, S. P., and Singh, P.K. (2015). Integrated nutrient management for quality production of cauliflower in acid alfisol of Nagaland. Karnataka J. Agril. Sci. 28(2): 244-247.

Workneh, F., Bruggen, A. H. C., Drinkwater, L. E. and Shennan, C. (1993). Variables associated with corky root and Phytophthora root rot of tomatoes in organic and conventional farms. Phytopathol. 83: 581-589.

\section{How to cite this article:}

Parkey Gogoi, Deepa Borbora Phookan and Utpal Das. 2018. Effect of Organic Inputs and Microbial Consortium on Yield and Soil Health of Knolkhol (Brassica oleracea L. var. gongylodes) Cultivation. Int.J.Curr.Microbiol.App.Sci. 7(04): 3465-3471. doi: https://doi.org/10.20546/ijcmas.2018.704.392 